\title{
Práctica convencional del Estado mexicano en el ámbito de la Organización de las Naciones Unidas
}

El periodo comprendido entre septiembre de 2014 y agosto de 2015, fue uno que no careció de actividad en la esfera del Derecho Convencional de la Organización de las Naciones Unidas. Así, México ratificó uno de los convenios fundamentales de la Organización Internacional del Trabajo (OIT) y fue uno de los primeros Estados en ratificar el Tratado de Marrakech, administrado por la Organización Mundial de la Propiedad Intelectual, asimismo ratificó la Convención de las Inmunidades Jurisdiccionales de los Estados y de sus Bienes, y el Convenio de Minamata en Materia de Medio Ambiente.

\section{DERECHO LABORAL}

\section{Convenio sobre la Edad Mínima de Admisión al Empleo}

El 10 de junio de 2015, México presentó su instrumento de ratificación sobre el Convenio 138 de la OIT, el mismo entrará en vigor para México, un año después de haberse depositado el instrumento, es decir, el 10 de junio de 2016. Esta ratificación deriva de la reforma del artículo 123 de la Constitución Política del 17 de junio de 2014, que aumentó la edad mínima laboral a 15 años. México aún falta por ratificar el Convenio núm. 98 sobre el derecho de Sindicación y de Negociación Colectiva de la OIT, en vigor desde 1951. 
Esta revista forma parte del acervo de la Biblioteca Jurídica Virtual del Instituto de Investigaciones Jurídicas de la UNAM

\section{PROPIEDAD INTELECTUAL}

1. Tratado de Marrakech, para facilitar el acceso a las obras publicadas a las personas ciegas, con discapacidad visual o con otras dificultades para acceder al texto impreso

El 29 de julio de 2015, México depositó con la Organización Mundial de la Propiedad Intelectual su instrumento de ratificación del Tratado de Marrakech, adoptado el 27 de junio de 2013 y que aún no está en vigor. Así, México es el séptimo país en ratificar el convenio, al que también han accedido Singapur y los Emiratos Árabes Unidos, y que entrará en vigor a los tres meses de haberse depositado el vigésimo instrumento de ratificación o adhesión.

\section{PRIVILEGIOS E INMUNIDADES, RELACIONES DIPLOMÁTICAS Y CONSULARES, ETCÉTERA}

\section{Convención de las Naciones Unidas sobre las inmunidades jurisdiccionales de los Estados y de sus Bienes}

El 29 de septiembre de 2015, México presentó su instrumento de ratificación para la Convención sobre las inmunidades jurisdiccionales de los Estados y de sus Bienes, en la Jornada de los Tratados en la ONU. La convención entrará en vigor en el trigésimo día a partir del depósito del trigésimo instrumento de ratificación, aceptación o aprobación o adhesión; hasta ahora, diecinueve Estados han manifestado su voluntad en alguna de estas maneras, por lo que la Convención no ha entrado en vigor.

\section{MEDIO AMBIENTE}

\section{Convenio de Minamata sobre el Mercurio}

El 29 de septiembre de 2015, México presentó su instrumento de ratificación para el Convenio de Minamata, en la Jornada de los Tratados de la ONU. De acuerdo con su artículo 1o. el Convenio tiene como objetivo proteger la salud humana y el medio ambiente de las emisiones y liberaciones 
antropógenas de mercurio y compuestos de mercurio. Hasta el 29 de septiembre, México y Panamá han sido los últimos Estados en ratificar la Convención, que entrará en vigor haya que se haya presentado el quincuagésimo instrumento de ratificación, aceptación, aprobación o adhesión. Hasta ahora, dieciocho Estados han manifestado su voluntad en alguna de estas maneras, por lo que el Convenio todavía no ha entrado en vigor.

Elaborado por Xavier J. Ramírez García de León 